\title{
A „CSALÁDI VÁLASZTÓJOG” ÉS A VÁLASZTÓJOGI KÉPVISELET KÉT LEHETSÉGES ÉRTELME
}

\author{
Könczöl Miklós \\ PPKE JÁK, MTA TK Jogtudományi Intézet
}

\begin{abstract}
ÖSSZEFOGLALÓ
Az utóbbi évtizedben Magyarországon is ismételten fölmerült az az alkotmányjogi javaslat, melynek értelmében a választójog alsó korhatárának eltörlésével a felnőttkort még el nem ért állampolgárok is rendelkezhetnének szavazattal, ezt azonban nem maguk, hanem - képviseletükben - a szüleik gyakorolhatnák („„családi választójog”). A javaslat azon törekvések sorába illeszkedik, melyek a fenntarthatósággal kapcsolatos problémákra igyekeznek alkotmányjogi válaszokat találni. A mellette fölhozott érvek azonban - legalábbis részben - túlmutatnak a fenntarthatóság kérdésén, és alapvető jog- és politikaelméleti problémákat vetnek föl. A dolgozatban a képviselet fogalmára koncentrálva vizsgálom a javaslatot. A családi választójoggal kapcsolatban kétféle értelemben is beszélhetünk képviseletről, s ennek nyomán két különböző, bár egymástól nem független, gondolatmenetet rekonstruálhatunk. Az egyik arra az elképzelésre épül, hogy az így leadott szülői többletszavazatok voltaképpen a gyermekek szavazatai, s ezért a javaslat nem sérti az egyenlő és közvetlen választójog követelményét. Ezzel szemben amellett érvelek, hogy a szülői szavazat esetében nem a gyermek politikai preferenciáinak puszta közvetítéséről van szó, és a döntéshozatalra képtelennek tekintett személyek képviselete ebben az értelemben nem lehetséges. A másik lehetséges gondolatmenet föladja a választójog egyenlőségének igényét, és éppen azzal indokolja a javaslatot, hogy a szülői többletszavazatok szükségesek a gyermekek érdekeinek megfelelő súlyú képviseletéhez. Ennek alátámasztásához úgy kell tekintetnünk a szülőket, mint akik másoknál alkalmasabbak a gyermekek érdekeinek képviseletére a politikai döntéshozatal során. Itt három, a szakirodalomban megjelenő tulajdonságra koncentrálok: az információkhoz való hozzáférésre, a közös érdekekre, valamint az önzetlenségre. Álláspontom szerint azonban ezek a körülmények vagy nem egyértelmúek, vagy irrelevánsak, következésképpen a második gondolatmenet sem alkalmas az így fölfogott családi választójog igazolására.
\end{abstract}

Kulcsszavak: politikai képviselet • választójog • alkotmányjog • családi választójog

\section{BEVEZETÉS}

Az alábbiakban azt a javaslatot vizsgálom meg, mely szerint a választójog alsó korhatárát eltörölve, a szülőknek kellene leadniuk kiskorú gyermekeik szavazatait („,családi választójog”). ${ }^{1}$ A javaslat több országban is ismételten fölmerült: a legismertebb az ezzel kapcsolatos, az 1970-es években kezdődött német vita, melynek érvei az errôl folyó magyar alkotmányjogi diskurzusban is meg- 
jelentek, de máshol is találunk hasonló elképzeléseket. ${ }^{2}$ A javaslat azokhoz az erőfeszítésekhez kapcsolódik, melyek célja, hogy intézményi válaszokat adjanak a fenntarthatósággal kapcsolatos problémákra, különösen az elöregedő társadalmakban (vö. van Parijs, 1998; Jakab, 2017). A viták során fölmerülő érvek és ellenérvek azonban túlmennek a hatékonyság kérdésén, ti. hogy a javasolt választójogi reform csakugyan fenntarthatóbb döntésekhez vezetne-e. A háttérben olyan alapvető alkotmányjogi, jog- és politikaelméleti kérdések állnak, melyeknek fogalmi tisztázása mindenképpen szükségesnek látszik a vita érdemi folytatásához. Dolgozatom ehhez kíván hozzájárulni, a képviselet fogalmára alapuló érvek közelebbi vizsgálatán keresztül.

Noha támogatói nemegyszer csodaszerként festik le a javaslatot, amely egyszerre nyújtana megoldást egy sor, a demokráciával és a fenntarthatósággal kapcsolatos kérdésre, megítélése mégis ellentmondásos. Legalább három szempontból vethetôk föl ellenérvek: egyrészt, hogy a szülői többletszavazatok bevezetése ellentmondana az egyenlő és közvetlen (személyes) választójog demokratikus (és többnyire alkotmányokba is foglalt) elvének (a kérdésről - a német alkotmányjog kontextusában - ld. Müller-Franken, 2013, további hivatkozásokkal); másrészt, hogy szükség sincsen rá, hiszen a választójog hiánya nem jelenti a gyermekek képviseletének a hiányát (ld. Pechstein, 1996: 84-85., idézi Müller-Franken, 2013: 59.); harmadszor pedig, hogy haszontalan volna, vagy azért, mert a szülői többletszavazatok nem föltétlenül szolgálnák a fenntarthatóságot vagy a gyermekek érdekeit (ld. pl. de Briey, 2007), vagy pedig azért, mert a szavazatok nem változtatnának jelentősen a szavazások kimenetelén. ${ }^{3}$ Ez utóbbival kapcsolatban említendő még az a paradoxon, mely szerint az efféle intézményi reformok éppen azokban a politikai közösségekben számíthatnak a bevezetésükhöz szükséges mértékủ támogatásra, ahol nincsen rájuk égető szükség (vö. Offe, 1994, idézi Goerres-Tiemann, 2009: 58.).

A vázolt ellenvetésekre válaszként vagy azokat megelőlegezve megfogalmazott érveket szokás "deontologikus" és "konzekvencialista" csoportokba sorolni (ld. pl. Reimer, 2004; de Briey, 2007; Goerres-Tiemann, 2009; ReimerSchanda, 2016; harmadikként említi az alkotmányjogi érveket Westle, 2006). Noha a kettő között egyes esetekben nehéz egyértelmú különbséget tenni, annyi bizonyos, hogy a kétfajta érv hatóköre eltér. Az előbbiek arra adnak magyarázatot, hogy miért legyen választójoga a gyermekeknek, az utóbbiak pedig arra, hogy miért szavazhassanak gyermekeik nevében a szülók ${ }^{4}$

A továbbiakban a vitának csak egy részterületére, a szülőket a gyermekek képviseletében megillető szavazatok kérdésére összpontosítok, két, véleményem szerint eltérő természetú gondolatmenetet vizsgálva meg. Az első ragaszkodik az egyenlő választójoghoz, s ennek megfelelően azon az elképzelésen alapszik, hogy ezek a szavazatok csakugyan a gyermekek szavazatai, a szülők csupán gyakorolják ezt a jogot gyermekeik nevében. A második, föladva ezt a megfelelési igényt, éppenséggel a szülők által leadható többletszava- 
zatok igazolására törekszik. Noha a gyakorlatban többnyire a két érvkészlet valamilyen kombinációjával találkozhatunk, a kettő mégis független egymástól, legalábbis annyiban, hogy a többletszavazatok melletti érvek akkor is meggyőzőek lehetnek, ha az egyenlő választójogból kiinduló gondolatmenet nem bizonyul tarthatónak.

A két gondolatmenetet egymás után veszem szemügyre, mindkét esetben a „képviseleti választójog” fogalmának nekik megfelelő értelméből kiindulva. Az egyenlő választójogi megközelítés esetében a fogalom egyik lehetséges értelme sem ad kellő alapot a családi választójoghoz. A többletszavazatokon alapuló megközelítés alapja a képviselet egy másik értelme, amelynek alapján több sikerrel érvelhetnénk valamiféle képviselőnek a döntéshozási folyamatba iktatása mellett. Ha azonban a szülői többletszavazatokra alkalmazzuk az érveket, ezek sem nyújtanak megfelelő igazolást.

\section{AZ EGYENLŐ VÁLASZTÓJOGHOZ KÖTŐDŐ ÉRVEK}

Tekintettel arra, hogy jelenleg a bizonyos életkornál fiatalabb állampolgárok nem rendelkeznek választójoggal, a családi választójog melletti érvelésnek legalább a következő állításokat magában kell foglalnia:

(1) A gyermekeknek rendelkezniük kell választójoggal.

(2) A gyermekek nem képesek szavazni.

(3) A szülőknek kell gyakorolniuk a gyermekeik választójogát.

A javaslat fönti formájában abból a föltevésből indul ki, hogy a szavazat a gyermek szavazata. A gyermekek, állampolgárok lévén, szavazati joggal bírnak (1), ${ }^{5}$ ugyanakkor viszont szükség van valakire, aki ezt a jogot gyakorolja a nevükben (2). Ez a megoldás gyakran jelenik meg úgy a szakirodalomban, mint amely megfelel az "egy személy - egy szavazat” alkotmányos elvének (ld. pl. ReimerSchanda, 2016: 64.). A családi választójog mellett érvelő szerzők hangsúlyozzák, hogy így a szülők egynél több szavazatot adhatnak ugyan le, a többletszavazatok nem az ő saját szavazataik. ${ }^{6}$ Ez azért bír jelentőséggel, mert a családi választójoggal szembeni legkézenfekvőbb kifogás, amint már említettem, az, hogy hatását tekintve nem különbözik a plurális választójogtól.7

Tekintettel arra, hogy az alábbiakban a szülők által leadható többletszavazatok kérdését vizsgálom, nem foglalkozom külön a fönt említett (1) és (2) állítással, hanem a vita kedvéért elfogadom őket. Ehelyett arra koncentrálok, hogy a képviselet fogalmának milyen értelmezésével támasztható alá a (3) állítás. Álláspontom szerint ez kétféleképpen lehetséges: az egyik esetben azt tekintjük képviselőnek, aki pusztán közvetíti a választójoggal rendelkező személy döntését, a másikban pedig a képviselő magát a döntést hozza meg a gyermek nevében. 
Azzal az ellenvetéssel szemben, hogy a családi választójog sértené a választójog közvetlenségének elvét (vö. pl. a német Grundgesetz 38. cikk (1) bekezdését), a meghatalmazott útján történő szavazás intézményére szokás utalni, amilyen pl. a brit voting by proxy vagy a francia vote par procuration. Ezek olyan lehetőségek, melyek mintegy a levélben történő szavazás mintáját követve segítenek azoknak az állampolgároknak, akik nem képesek személyesen leadni szavazatukat (ld. pl. Löw, 2002; Fröhlich, 2011). Az ezzel élni kívánó választópolgároknak külön jelezniük kell ezt az igényüket, meghatalmazva egy olyan személyt, aki maga is rendelkezik választójoggal (vö. a Representation of People Act 2000 12. cikkének (1) bekezdését, ill. a Code électoral 147bis cikkét). Ebben az értelemben tehát a "képviselő" olyasvalaki, aki a szavazáshoz kötődő külső aktusokat végzi el meghatalmazója nevében, az óáltala meghozott politikai döntést közvetítve ezáltal. Látnunk kell azonban, hogy a családi választójog felől nézve a párhuzam nem túlságosan közeli. A meghatalmazott útján történő szavazás lehetôségével azok élhetnek, akik maguk is gyakorolhatnák szavazati jogukat, ha nem volnának ebben akadályoztatva. ${ }^{8} \mathrm{~A}$ családi választójogot támogatók viszont abból indulnak ki, hogy a gyermekek egyéb körülményektől függetlenül sem képesek gyakorolni választójogukat - tehát akkor sem, ha nincsenek akadályoztatva.

A fönti értelemben az lehet alkalmas képviselő, aki egyrészt fizikailag és jogilag is képes leadni a szavazatot, másrészt pedig várhatóan az akadályoztatott választópolgár szavazatát fogja leadni, ti. úgy szavaz, ahogy amaz is tenné, mintegy az ő utasítását hajtva végre. A „meghatalmazó” természetesen megteheti, hogy rábízza képviselőjére, hogyan szavaz. ${ }^{9}$ Az intézmény mindazonáltal föltételezi, hogy az előbbi legalábbis képes rá, hogy maga hozza meg azt a döntést, melyet az utóbbi által leadott szavazat révén juttat kifejezésre. Ezzel szemben a családi választójog esetében a képviselet láthatólag nem csupán a szavazat leadására utal (ti. hogy az illető kitölti a szavazólapot és elhelyezi az urnában, vagy hasonló cselekvést végez), hanem a döntéshozatal mozzanatát is magába foglalja (vö. Gaa, 1997: 345.). Úgy látszik, a családi választójog támogatói is ez utóbbi értelmezésból indulnak ki, s a voting by proxy párhuzamával csupán arra kívánnak rámutatni, hogy a választójog közvetlensége nem igényli, hogy az állampolgár személyesen adja le a szavazatát (ld. pl. Reimer-Schanda, 2016: 182.).

\section{A döntéshozatal}

A családi választójog s ezen belül is a szülői képviselet egyik előföltevése, hogy a gyermekek általában véve nem képesek a politikai döntéshozatalra, a másik 
viszont az, hogy mások képesek ezt helyettük megtenni. A kérdés, mint jeleztem, az, hogy ez nem sérti-e a választójog közvetlenségének elvét. Az erről folyó vitában olykor fölmerül párhuzamként a házasságkötés is. A családi választójog ellenzői úgy érvelnek, hogy egyes személyhez kötődő döntéseket csak maguk az érintettek hozhatnak meg, mások nem. Manapság - így az ellenzők - ezek közé tartozónak tekintjük a házasságkötést és a demokratikus döntéshozatalt is (ld. pl. Gaa, 1997: 345.; Hinrichs, 2002: 52.). A támogatók ezzel szemben úgy érvelnek, hogy a szavazás természete különbözik a házasságkötésétől, hiszen az utóbbi abban az értelemben személyes döntés, hogy következményei alapvetően meghatározzák a házasulók egyéni sorsát, a szavazás hatása viszont nem kötődik ilyen közvetlenül a választópolgár személyéhez (ld. Hattenhauer, 1996: 16.; Reimer, 2004). ${ }^{10}$ Utóbbiak szerint a képviselő szavazata révén nem a személyes preferenciáknak, hanem az érdekeknek kell kifejezésre jutniuk. Ha - szemben más korok és más kultúrák meggyőződésével - úgy gondoljuk is, hogy a házastárs megválasztását nem végezheti más a házasulandók helyett, okkal hihetjük, hogy a politikai döntéshozatal szempontjából releváns érdekeinket más személyek is megfelelő módon képviselhetik.

Ebben a megközelítésben a szülőket az teszi alkalmas, sőt a legalkalmasabb képviselőkké, hogy közel állnak a gyermekekhez. Ez a közelség egyaránt kiterjed az információkra és a motivációkra. Egyrészt föltehető, hogy a szülők általában tájékozottak a gyermekeik személyes érdekeit illetően, hiszen viszonylag sok időt töltenek velük. Másrészt pedig számolhatunk azzal, hogy érzelmi kötődésük arra indítja őket, hogy megfontolják, milyen lehetséges hatásokkal jár az adott döntés a gyermekeikre nézve. Ehhez kapcsolódik az a föltevés is, hogy ha a gyermekek történetesen rendelkeznek valamilyen választói preferenciával, akkor a szülők képesek és készek azt figyelembe venni (ld. Schanda, 2012). Itt az iskoláztatással kapcsolatos döntések említhetők párhuzamként: a szülők választják ki a gyermekek iskoláit, ugyanakkor elvárható (és föltehetô), hogy a döntés során tekintettel legyenek az ő véleményükre is. ${ }^{11}$ A motivációs föltevés a szavazás aktusára is kiterjeszthető: a családi választójog támogatói elismerik, hogy lehetnek érdekkonfliktusok szülők és gyermekek között, ugyanakkor állítják, hogy a szülőktől várható a leginkább, hogy e tekintetben is önzetlenül járjanak el, tekintetbe véve az utóbbiak érdekeit, adott esetben akár megosztva a leadott szavazatokat (vö. Schanda, 2012: 83.; Reimer-Schanda, 2016: 68.).

Egy hasonló gondolatmenet azon alapul, hogy szülők és gyermekeik különleges kapcsolatát a legtöbb modern jogrendszer elismeri, amikor a szülőket ruházza föl döntési joggal a gyermekek vagyoni és egyéb jogainak gyakorlása körében. A gyermekeknek vannak olyan jogaik, amelyeket nem képesek maguk gyakorolni, ahogy olyan kötelezettségeik is lehetnek, amelyeknek nem tudnak saját cselekedeteik útján eleget tenni (vö. Steffani, 1999: 792.). Jogképességük kiterjedhet a tulajdonszerzésre, pl. öröklés útján, az ehhez kapcsolódó dönté- 
sek azonban már a cselekvőképesség körébe tartoznak, amivel viszont a kiskorúak nem rendelkeznek. A szülők joga és kötelessége, hogy ezeken a területeken a gyermekek érdekének megfelelően döntsenek és járjanak el (vö. Merk, 2009: 535.). Ez az érvelés nem csupán a koherencia igényére támaszkodik (ti. hogy a választójogot is a tulajdonjoghoz, az oktatási jogokhoz stb. hasonlóan lenne helyes szabályozni), hanem egy analógiára is: ha a törvényhozó egy sor területen kifejezi a szülő mint a gyermek érdekeinek (sőt preferenciáinak) képviselője iránti bizalmát, az a választójoggal kapcsolatban is követendő (ld. pl. Nopper, 1999: 151.).

A szülők mint a gyermekek helyett szavazó képviselők alkalmasságának kérdését a következő pontra hagyva, egyelőre azt a következtetést vonhatjuk le, hogy a családi választójog a képviselet olyan értelmezéséhez kötődik, mely szerint a szülők a döntéshozatal (és nem pusztán a szavazat leadása) mozzanata során is a gyermekek helyett cselekszenek. A szavazásra korlátozott értelmezés csak arra szolgál, hogy létező és alkotmányossági szempontból nem kifogásolt párhuzamokat vonultasson föl a javasolt intézmény mellett. Ha viszont úgy tekintjük, hogy a szülők a gyermekeik nevében döntést hoznak, akkor fölmerül a kérdés, hogy a (2) és a (3) állítás összefér-e, azaz hogy lehetséges-e olyan személy képviseletében döntést hozni, akit személyében nem tekintünk alkalmasnak arra, hogy maga hozza meg az illető döntést.

Ha kitartunk amellett, hogy a szülő ebben az esetben a gyermek választójogát gyakorolja, akkor az előbbitôl nem csupán azt várjuk, hogy tekintetbe vegye az utóbbi érdekeit vagy preferenciáit. A választójog egyenlőségén alapuló gondolatmenet (mely az egyenlő és közvetlen választójog követelményének volna hivatott megfelelni) értelmében a szülőnek nem csupán formai, hanem tartalmi értelemben is képviselnie kell a gyermeket, tehát olyan döntést kell hoznia, amilyet a gyermek is hozna (formális és tartalmi képviselet különbségéről ld. Böckenförde, 1982: 318-322.). A problémát itt az jelenti, hogy a gyermekek esetleg egyáltalán nem hoznak politikai döntéseket. Elképzelhető, hogy az ember már igen korán rendelkezik preferenciákkal pl. az oktatást vagy a vallásgyakorlást illetően, ${ }^{12}$ ez azonban nem föltétlenül igaz a politikára. Ha föltesszük, hogy a gyermekek általában a jelenlegi szabályozás által tükrözött életkornál hamarabb kialakítják politikára vonatkozó nézeteiket, pl. 18 helyett már 16 vagy 14 évesen, akkor erre a korhatár leszállítása látszik megfelelő válasznak. ${ }^{13}$ Ha viszont úgy gondoljuk, hogy egyes gyermekeknek életkoruk alapján nem tulajdoníthatunk politikai preferenciákat (ehhez ld. pl. Rosenberg, 2016), akkor képviseletról sem beszélhetünk ebben az értelemben.

A családi választójog támogatói azonban a jelek szerint nem az egyéni döntések kifejezéseként tekintenek a szavazásra, hanem arra koncentrálnak, hogy a javasolt változtatás milyen hatással volna a szavazópolgárok közösségének összetételére és ezáltal a szavazás várható eredményére. Éppen ezért valójában nem is a szavazati jog egyenlősége, hanem a leadható szavazatok számá- 
nak az egyenlőtlensége foglalkoztatja őket. Erre az egyenlőtlenségre szerintük azért van szükség, hogy a gyermekek érdekei megfelelő súllyal essenek latba, valamint hogy környezeti vagy társadalmi hatásukat tekintve fenntartható politikai döntések születhessenek.

\section{A PLURÁLIS VÁLASZTÓJOGHOZ KÖTŐDŐ ÉRVEK}

Ha a gyermekek nevében szavazó szülőkre az érdekek képviselőiként tekintünk, az alapvetően megváltoztatja a gondolatmenetet. Ebben az esetben az (1) és a (3) állítás helyébe a következők lépnek:

$\left(1^{\prime}\right)$ A gyermekek érdekeinek nagyobb súllyal kell megjelenniük a demokratikus döntéshozatal során.

(3’) A szülőknek többletszavazatokat kell juttatnunk, hogy hatékonyabban képviselhessék ezeket az érdekeket.

$\mathrm{Az}\left(1^{\prime}\right)$ állítás a családi választójoggal kapcsolatban leggyakrabban fölhozott érv, és önmagában nem is mond ellent az egyenlő választójog elvének. A (3') viszont jóval egyértelmúbben arra irányul (s ezért kevésbé gyakran is jelenik meg), hogy megváltozzanak a jelenlegi erőviszonyok. A mi számunkra azonban érdekesebb most azt megfigyelni, hogy a (3) melletti, röviden (az 1.2. pontban) már említett érvek ez utóbbi igény mellett is fölhozhatók. A továbbiakban ezeket fogom sorra venni: először a szülők információhoz való hozzáférésére alapuló érvet, majd az önzetlenség érvét, végül pedig egy harmadikat, melynek értelmében a szülók még akkor is alkalmasabbak másoknál a gyermekek érdekeinek a képviseletére, hogyha nem tájékozottabbak vagy önzetlenebbek náluk, mivel ezek az érdekek jórészt egybeesnek az ő saját érdekeikkel.

\section{Tájékozottság}

Ami az első érvet illeti, a kérdés az, miért gondoljuk, hogy a szülők több információval rendelkeznek a gyermekek érdekeivel kapcsolatban, mint más lehetséges jelöltek (pl. tanárok, civil szervezetek vagy különféle területeken müködő szakértők). A személyes közelségből kiindulva az a válasz látszik kézenfekvőnek, hogy a szülők számos információhoz közvetlenül hozzáférnek a gyermekek személyes igényeit és szükségleteit illetően. Még ha nem is ők azok, akik a legtöbb időt töltik a gyermekeikkel, mindazonáltal számos helyzetben vannak együtt. Emellett a szülői figyelem alkalmasint kevésbé oszlik meg, mint pl. a tanároké, akiknek egyszerre kell számos gyermekkel foglalkozniuk. Hasonlóképpen a szülők azok, akik a legtöbbet tudhatnak a gyermekek személyes preferenciáiról. Ez különösen igaz a politikai nézetekre, melyek alaku- 
lására gyermekkorban nagyobb befolyással vannak a szülők, mint pl. a kortárs csoportok.

Ezen a ponton érdemes egy újabb pillantást vetnünk a szülői döntéshozatal már említett párhuzamaira. Az iskolaválasztásról például elmondhatjuk, hogy azért a szülők dolga, mert ők tudják a legszélesebb körben mérlegelni a gyermek egyéni szükségleteit és preferenciáit, valamint a pillanatnyilag elérhető lehetőségeket. Hasonlóan gondolkodhatunk, bár talán kevésbé kategorikusan, a pénzügyi természetû döntésekről. E párhuzamok közös vonása, hogy a döntések olyan helyzetben születnek, amely valamiképpen hatással lesz az illető gyermek személyes jövőjére: testi és szellemi fejlődésére, egészségére, társas kapcsolataira, anyagi helyzetére stb. A házasságkötéssel kapcsolatos érvvel szemben ugyanakkor arra szokás rámutatni, hogy lényegileg különbözik a szavazástól, hiszen az utóbbinak a hatása nem kötődik szorosan a döntéshozó személyéhez.

Ha úgy tekintünk a szülókre, mint akik a gyermekek érdekeit képviselik a döntéshozatal során (azaz nem az általuk már meghozott döntéseket közvetítik), az így képviselt érdekek és preferenciák elveszítik szigorúan vett személyes jellegüket. A családi választójog támogatói ráadásul úgy tekintenek a politikai döntésekre, mint amelyek abban az értelemben is személytelenek, hogy jóllehet a szavazat leadásakor a választópolgárt személyes érdekei motiválhatják, a "képviselői” szavazatok révén azok a preferenciák fejeződnek ki, amelyeket a szavazók az általuk képviselt személyeknek tulajdonított érdekek figyelembevételével alakítottak ki. Ilyenformán viszont hiába mondhatjuk, hogy a szülők csakugyan kivételes helyzetben vannak a gyermekeik személyes érdekeinek ismeretét illetően, ez nem jelenti egyszersmind, hogy akkor is az átlagnál jobb döntést hoznak, hogyha a gyermekeknek mint gyermekeknek az érdekeit (például a felnőttekkel vagy az idősebbekkel szembeállítva) kell figyelembe venni. A szülők minden további nélkül hozhatnak kompetens döntést, ez azonban nem a saját gyermekeikhez füződő személyes viszonyuk következménye. Más szóval, ha úgy érvelünk, hogy a családi választójog nem ütközik a választójog személyességének az elvébe, valamint hogy a gyermekek (mint csoport) érdekeit hatékonyabban jelenítenék meg a szülőknek juttatott többletszavazatok, akkor szembe kell néznünk vele, hogy e „képviseleti" szavazatok megfontolt leadásához szükséges információ nem azonos azzal, ami kizárólag a szülőknek (mint szülőknek) áll a rendelkezésére. Más, sajátos információforrásokhoz hozzáférő szakértők és döntéshozók alkalmasint megfelelőbb jelölteknek látszanak ezeknek az érdekeknek a képviseletére. 


\section{Önzetlenség}

A második érv alapja az az elképzelés, hogy a szülők azért képviselik másoknál jobban a gyermekeket a politikai döntéshozatalban, mert nagyobb önzetlenséggel viseltetnek velük szemben (vö. Reimer-Schanda, 2016: 182.). Negatív megközelítésben azt mondhatjuk, hogy magának a javaslatnak a motivációja is a gerontokrácia következtében érvényesülő generációs önzés ellensúlyozása. Fontos megjegyezni, hogy gerontokráciának önmagában nincs pejoratív tartalma: a politikai eszmék történetére visszatekintve látjuk, hogy számos szerző helyeselhető elvként mutatja föl (vö. Cupti, 1998; Palmore, 1999: 45.). Csak akkor merül föl problémaként, ha a generációk közti viszonyt érdekek ütközéseként fogjuk föl. Ebben a pontban részben azzal foglalkozom, hogy indokolte ez utóbbi megközelítés, részben pedig azzal, hogy a családi választójog alapjaként csakugyan elfogadhatjuk-e a szülők önzetlenségét.

A nemzedékek közti élesedő (érdek)ellentétekről azoknak a változásoknak az alapján szokás beszélni, amelyek az életkor-specifikus szakpolitikákat, valamint a politikai attitűdöket jellemzik. Az előbbiekre jó példa lehet a gyermekszegénység és az időskori szegénység alakulásának különbsége a nyugati társadalmakban (ld. pl. Peterson, 1992; Hinrichs, 2002), vagy a megszorítások eltérő mértéke a nyugdíjak és az oktatási kiadások terén. Ami pedig az attitűdöket illeti, a közvélemény-kutatások ugyancsak eltérést mutatnak korcsoportonként az idősebbek, illetve a fiatalabbak számára kedvezőbb politikák támogatását tekintve.

Az effajta adatok azonban sokszor korántsem egyértelmúek, és sok mindent ki lehet olvasni belőlük. A rájuk épülő érveket pedig gyakran bírálják azért, mert nem veszik tekintetbe a privát transzfereket. Elképzelhető például, hogy a nagyszülők anyagilag támogatják gyermekeiket és unokáikat, ezáltal közvetve a fiatalabbak szolgálatába állítják az idősebbekre költött forrásokat - mindez azonban láthatatlan marad, ha a vizsgálódásunk csak az állami kiadásokra terjed ki. Szélesebb körű kutatás tehát árnyaltabb képet adhat a nemzedékek közti kapcsolatokról. Az attitűdöket tekintve is hasonló lehet a helyzet: legalábbis nem magától értetődő, hogy az idősebbeknek nincsenek szoros személyes kapcsolatai a fiatalabbakkal, például a nagyszülőknek az unokákkal. Mindezek alapján elhamarkodottnak látszik az a szembeállítás, amelyet a gerontokrácia fogalmának használata sugall.

De ha elfogadjuk is a különböző korcsoportok közti érdekkonfliktusok létezését (márpedig ez egészében véve nehezen tagadható), akkor sem egyértelmü, hogy mi következik mindebből a javaslatra nézve. A családi választójog egyfelől a szülőknek juttatna többletszavazatokat, másfelől az emellett szóló leggyakoribb érv, hogy ők életkoruk és a gyermekeikhez füződő kapcsolatuk miatt hosszabb távon gondolkodnak. Ebből egy kettős szembeállítás következik: szülók - nem-szülók, illetve szülók - idősebbek. Ezzel pedig az a probléma, 
hogy ha az idősebbekre tekintünk úgy, mint akiknek kevésbé jövőorientált a gondolkodása, s a családi választójog valóban a gerontokrácia ellenszere, akkor nem más, mint pótlék a választójog fölső korhatára (az idősebbek szavazati jogának megvonása) helyett. A szülők nem szülő voltukra tekintettel kapják a többletszavazatot, hanem mint - átlagosan - fiatalabb emberek. Így viszont az egyazon korcsoporthoz tartozók közt keletkezik egyenlőtlenség, hiszen akinek gyermeke van, az több szavazatról dönthet, mint akinek nincs - miközben az idősebbek között nem teszünk hasonló különbséget.

Az sem jelenthető ki, hogy az idősebbek tipikusan gyermektelenek volnának. Éppen ellenkezőleg, a jelenleg élő generációk közül a korábbiakra magasabb termékenységi ráta (volt) jellemző, mint a fiatalabbakra. Ha tehát a gyermekek nevelése többlethatalmat igazol, akkor a nagyszülők sem volnának esélytelen jelöltek a gyermekek szavazatainak leadására. Megjegyzendő ugyanakkor, hogy ez a helyzet megváltozhat: a jelenlegi trendek mellett az idősebbek közt egyre nagyobb arányban lesznek a gyermektelenek (ld. pl. Van Parijs, 1999: 315.), jóllehet még így is több szülő lesz köztük, mint az utánuk születettek között.

Két további megfontolás is kétséget ébreszthet, hogy a (fiatalabb) szülők valóban a legönzetlenebb képviselői-e a gyermekeknek, akár a gyermektelenekhez, akár az idősebbekhez hasonlítva. Mindkettő ahhoz a különbséghez kapcsolódik, amely a saját gyermekekkel szembeni önzetlenséget választja el a fiatalabbakkal szembeni általános önzetlenségtől. Először is, éppen azért, mert nemcsak magukról, hanem a gyermekeikről is gondoskodniuk kell, a szülők körében a családok fejenkénti bevétele jóval alacsonyabb lehet, mint azonos korosztályban a gyermekteleneké. ${ }^{14}$ Ez pedig inkább rövidlátásra ösztönöz: ha nem is az attitúdöket, de a gyakorlatot illetően, hiszen egyszerúen nem engedhetik meg maguknak az altruizmus fényưzését (így már Weber, 1958, valamint őt idézve de Briey, 2007). Másodszor pedig az idősebbekhez képest a (fiatal) szülőknek több hasznuk lehet a időseknek járó nagyvonalú támogatásokból úgy a jelenben, mint a jövőben. Egyfelől az idősebb korosztályok közösségi támogatása enyhíti azt a terhet, amelyet saját szüleink ellátása jelent. Másfelől a fiatalabbak hosszabb időn keresztül élvezhetik majd ezeket a támogatásokat maguk is, különösen a várható élettartam nyugati társadalmakat jellemző emelkedése mellett (vö. - Andrew Williamsre hivatkozva - Van Parijs, 1999: 323. és 72. j.).

Önzés és önzetlenség kérdése más szempontból is fölvethető a családi választójoggal kapcsolatban. Fölvethető, hogy a jelenlegi rendszer, amely azon a vélelmen alapszik, hogy minden szavazó tekintettel van a politikai közösség szavazattal nem rendelkező tagjainak az érdekeire is, túlságosan magas morális elvárásokat támaszt az előbbiekkel szemben, legalábbis azok esetében, akiknek nincs szorosabb kötődésük az utóbbiakhoz. A családi választójog ebben a megközelítésben levenné ezt a morális terhet a választópolgárok válláról 
(Adrian, 2016). A föntiekből mindazonáltal látszik, hogy ez a teher a szülők esetében is jelen van, hiszen lehetnek a gyermekekével ellentétes érdekeik, vagy olyan érzelmi és egyéb kötelékeik, melyek a politikai döntéshozatal tekintetében más-más irányt jelölnek ki számukra.

De vannak gyakorlatiasabb, ugyanakkor talán súlyosabb érvek is azzal szemben, hogy választók csoportjait önzőnek vagy szúklátókörűnek bélyegezzük. Egyrészt az ilyen megkülönböztetés gyöngíti a morális egyenlőség érzését a politikai közösség tagjaiban. Másrészt, és talán ez a fontosabb, a diszkrimináció érzése - legyen az életkor- vagy családi állapot-alapú - egységes választói magatartásra ösztönözheti ezeket a csoportokat, noha jelenleg a legkülönbözőbb politikai preferenciák jellemzik őket (de Briey, 2007).

Mint láttuk, az „önzetlen képviselők" érve azt föltételezi, hogy az egyes (kor)csoportok érdekei - és a hozzájuk kapcsolódó attitûdök - egyfelől világosan megkülönböztethetők, másfelől szemben állnak egymással. Ez az elképzelés önmagában véve sem látszik vitathatatlannak, akár alapjait, akár gyakorlati következményeit tekintve, ám fontosabb, hogy a szülők részéről föltételezhető személyes altruizmus nem fordítható le egykönnyen generációk közti önzetlenségre. A következő pontban azt az érvet veszem szemügyre, mely szerint nincs is szükség ilyesfajta önzetlenségre.

\section{Közös érdekek}

Valamennyi eddigi megfontolással szemben élhetünk azzal az ellenvetéssel, hogy a szülők akkor is a legalkalmasabbak a gyermekek érdekeit megjeleníteni hivatott többletszavazatok leadására, ha nem ismerik jobban ezeket az érdekeket és nem is önzetlenebbek másoknál, egyszerüen azért, mert helyzetük sok tekintetben közel áll a gyermekekéhez. Érdekeik nagymértékben egybeesnek vagy összefüggnek. ${ }^{15}$ Az elsőre példa lehet a családok anyagi támogatása: ez egyaránt hasznára van a szülőknek és a gyermekeknek, ráadásul ez választja el őket más csoportokból, akiknek nem járnak ilyen támogatások. A szülők eszerint nem szorulnak semmilyen többletinformációra vagy önzetlen indíttatásra akkor, amikor a családtámogatást érintő politikai döntést kell meghozniuk, hiszen saját érdekeiket követve egyúttal gyermekeikét is érvényre juttatják. Inkább az igényel odafigyelést, hogy az így biztosított erőforrásokat megfelelően használják föl. A második eset, amikor nem esnek egybe az érdekek, viszont szorosan összefüggnek: erre lehet példa az oktatás finanszírozása, ami a képzettebb munkaerő magasabb jövedelme révén a későbbiekben magasabb összegú nyugdíjak kifizetését teszi lehetővé.

Ez az érv csakugyan kétséget ébreszthet, hogy a szülőknek ismerniük kelle a gyermekek sajátos érdekeit, vagy hogy önzetleneknek kell-e lenniük ahhoz, hogy az utóbbiak javát szolgáló döntéseket hozzanak. Mégis úgy látszik, hogy 
valamifajta információra mindenképpen szükségük van. Egy efféle „láthatatlan kéz" múködéséhez a szülőknek nem(csak) a gyermekek érdekeivel kell tisztában lenniük, hanem a magukéval (is). A fenntarthatósági problémák tekintélyes része nem a generációs önzés következménye, hanem a döntéshozók saját érdekeire vonatkozó szúklátókörúségé. Más irányból közelítve pedig az az ellenérv merülhet föl, hogy az érdekközösség nem korlátozódik a szülőkre: az idősebb nemzedékek bármely tagját kedvezően érintik a magasabb nyugdijak, s ezért van okuk arra, hogy ésszerü befektetésnek tekintsék az oktatás közösségi finanszírozását. Ugyanez igaz az érzelmi kötelékekre is, melyek szülők és gyermekek kapcsolatán kívül is lehetségesek. Egyfelől tehát a szülők helyzete nem látszik egyedülállónak a motivációt tekintve, viszont azt sem mondhatjuk, hogy az érdekek egybeesése kompenzálná a tájékozottság hiányát a döntéshozatal eredményét illetően.

\section{ÖSSZEGZÉS}

A föntiekben a családi választójog melletti és elleni, a képviselet fogalmához kötődő érveket igyekeztem rendszerezve áttekinteni, megvizsgálva összefüggéseiket és a velük szemben fölmerülő ellenvetéseket. Ennek során nem követtem a deontikus és konzekvencialista érvek mára bevettnek mondható megkülönböztetését, hanem az alapján osztottam föl őket, hogy megmaradnak-e a választójog egyenlőségének határain belül, vagy túllépnek rajta. Az előbbiek azt az alkotmányos-dogmatikai konstrukciót tekintik kiindulópontjuknak, mely szerint a szülők nem plurális választójogot gyakorolnának, hanem a sajátjuk mellett a gyermekeik szavazatait adnák le, mintegy az ő képviseletükben szavazva. Ez az értelmezés azonban nehezen tartható, s a családi választójog hívei gyakran hoznak föl a szavazati jogok egyenlőtlen elosztására irányuló érveket is. Ez utóbbiakon belül három típust különböztettem meg. Az első szerint a szülöi képviselet indoka az ő tájékozottabb döntéshozataluk; a második szerint az, hogy a többletszavazatokat önzetlenül használnák föl; a harmadik szerint pedig, hogy az érdekek egybeesésének köszönhetően akkor is a gyermekek érdekeit képviselnék, ha annak nincsenek tudatában. Mindháromfajta érvvel kapcsolatban rámutattam, hogy részben vitathatók, részben pedig nem támasztják alá a családi választójog szükségességét.

Az eddigiekben elmondottakat nem ismételve végül kiemelendő, hogy a kétféle gondolatmenettel kapcsolatos megállapítások következményei is eltérnek. A választójog egyenlőségénél maradva, a képviseleti választójog ott megfogalmazott két lehetséges értelmezésével kapcsolatos fogalmi problémák azt mutatják, hogy a családi választójog nem védhető azzal a váddal szemben, hogy megsérti a választójog egyenlőségének elvét. A mellette szóló érvek ugyanakkor nem egyformán érzékenyek erre az ellenvetésre. Sőt, a családi 
választójog támogatói mondhatják, hogy a gyermekek érdeke erőteljesebb képviseletének előnyt kell élveznie a jelenleg elfogadott alkotmányos elvekkel szemben. A dolgozat második felében a szülői (tehát a gyermeki érdekeket képviselőknek járó) többletszavazatok melletti érveket vizsgálva az ezzel szembeni ellenvetéseket is bemutattam. Ezek alapján, ha elfogadjuk is a plurális választójog gondolatát, úgy látszik, hogy nem a szülők a legalkalmasabb jelöltek e többletszavazatok leadására. A tanulság talán akként összegezhető, hogy ha a politikai döntéshozatal hiányosságait kívánjuk orvosolni, akkor nem a választói csoportok erőviszonyainak a kérdésére kell összpontosítanunk, a politika decizionista megközelítéséből kiindulva, hanem inkább arra, hogy hogyan tehető tartalmasabbá a döntés pillanatát megelőző mérlegelés, és hogyan építhetók be ebbe a hosszabb távra tekintő perspektívák.

\section{JEGYZETEK}

1 A tanulmány alapjául szolgáló kutatást az OTKA K 112900 számú pályázata (Intézményi reformok öregedő társadalmakban: jogi és politikai aspektusok) támogatta. Köszönettel tartozom Jakab Andrásnak, Komáromi Lászlónak, Szente Zoltánnak, valamint a folyóirat anonim lektorainak javaslataikért és észrevételeikért.

2 Elsőként Löw, 1974. Az ezt követő vitáról ld. Westle (2006) áttekintését. Noha az elképzelést több képviselőcsoportból is támogatták a német szövetségi parlamentben (vö. Jesse, 2003: 8-9.), a reform bevezetésére végül nem került sor. A vita mindazonáltal tovább folyik (legújabban ld. Adrian, 2016). Magyarországon a rendszerváltás óta több ízben is megfogalmazódott a javaslat. 2011-ben az alkotmányozást megelőző „nemzeti konzultáció” kérdőívén is szerepelt a szülőknek járó többletszavazatokról szóló kérdés, a válaszadók többsége azonban nem támogatta ezt a megoldást. Az alkotmányjogi szakirodalomból 2011 óta ld. Fröhlich (2011) és Schanda (2012) a javaslat mellett, Jakab (2017) gyakorlati fönntartásokkal, Bodnár (2014), M. Balázs (2017; 2018) és Kurunczi (2018) ellene. Más országokban megjelent hasonló elképzelésekről ld. van Parijs, 1998: 309-310.; Reimer-Schanda, 2016: 63-64.; továbbá de Briey-Héraut-Ottaviani (2009) a belga plurális családi választójogról a 19-20. század fordulóján, és Bertaux (2011: 126-127.) egy hasonló francia javaslatról az 1910-es és 20-as években.

3 A meggyőző empirikus érvek hiányáról ld. Westle, 2006; Kahl, 2009; mindkettőt idézi MüllerFranken, 2013: 104. Ld. továbbá Goerres-Tiemann (2009) a német szövetségi választások eredményei alapján: következtetésük szerint az életkor befolyásolhatja ugyan a választói viselkedést, a családi választójog bevezetése mégsem hozott volna jelentős változást az 1995-2005 közötti választások eredményeit tekintve. A szülők csoportján belüli érdekkonfliktusok lehetőségét emeli ki Wernsmann, 2005: 66.

4 Kivétel ez alól, ha úgy tekintjük, hogy a szavazat a polgárok javai közé tartozik (ld. Hermann, 2011: 44-45.), s azzal érvelünk - deontologikus alapon -, hogy a szülők megérdemlik, hogy többet kapjanak belőle (minthogy gyermekeik révén magánjavaikból közjavakat állítanak elő). 
Hasonló érvet fogalmaz meg (többek között) Vanhuysse, 2013. Ezzel az állásponttal a továbbiakban külön nem foglalkozom, csupán jelzem, hogy meggyőzőnek látszik az az ellenvetés, mely szerint ezen az alapon korántsem csak a szülőknek kellene többletszavazatokhoz jutniuk (vö. Westle, 2006).

5 Ennek alátámasztásaként a népszuverenitásra szokás hivatkozni: minthogy - úgymond - a gyermekek is a „nép” részei, nem zárhatók ki a szuverenitás szavazás útján történő gyakorlásából (ld. pl. Peschel-Gutzeit, 1999: 560.; Merk, 2009: 531-534.; Schanda, 2012: 81.; Reimer-Schanda, 2016: 73.). Egy hasonló érv az emberi méltóság elismeréséhez kapcsolja a választójogot (ld. pl. Knödler 1996: 559-561.; Schreiber, 2004: 1344.; Löw, 2005: 34-35.; Merk, 2009: 534.).

6 Ezért szokás a "gyermekek képviselőik útján gyakorolt választójogáról” beszélni („children's vote vicariously exercised”, rövidítve ChiVi vagy KiVi, ld. pl. de Briey, 2007), vagy „helyettesítő választójogról” („Stellvertreterwahlrecht”, ld. pl. Müller-Franken, 2013: 6-7.). Ebben a dolgozatban a „családi választójog" kifejezést használom az intézményre, mert magyarul ez a legkevésbé nehézkes, s egyben a szülők szerepére is utal, amelynek kérdései állnak az itt szereplő fejtegetések középpontjában.

7 Ld. pl. de Briey-Héraut-Ottaviani, 2009. A családi választójog ellenzői ugyanezért úgy érvelnek, hogy nincsen gyakorlati különbség aközött, ha a szülők a többletszavazatokat sajátjukként, vagy ha gyermekeik képviseletében adják le: ld. pl. Wernsmann, 2005: 54-55.

8 Vö. Müller-Franken, 2013: 78., arra is rámutatva, hogy a fönti értelemben vett „képviseleti szavazás" a választójoggal rendelkező személy kifejezett akaratán múlik, s a törvény csak arra ad módot, hogy az illető nevében egy őt képviselő személy adja le a szavazatot.

9 Ld. Löw, 2005: 38-39., Lionel Jospin francia exelnök példájával, aki 2002-ben nem jutván az elnökválasztás második fordulójába, állítólag úgy nyilatkozott, hogy egy barátját fogja meghatalmazni, hogy a nevében szavazzon, mert ő maga nem tud választani a versenyben maradt jelöltek közül.

10 Ld. még Schanda, 2012: 83., aki hangsúlyozza, hogy a választójog személyessége nem szerepel az alkotmányos követelmények között.

11 Ld. általánosságban az ENSZ gyermekjogi egyezményének (UN Convention on the Rights of the Child) 12. cikk 1. pontját, mely szerint „az Egyezményben részes államok az ítélőképessége birtokában lévő gyermek számára biztosítják azt a jogot, hogy minden ôt érdeklő kérdésben szabadon kinyilváníthassa véleményét; a gyermek véleményét figyelemmel korára és érettségi fokára, kellően tekintetbe kell venni".

12 A vallás terén pl. a német Gyermekek vallási neveléséról szóló törvény (RelKErzG) úgy rendelkezik, hogy a gyermek tizenkettedik életévének betöltése után nem köteles akarata ellenére vallást változtatni, tizennegyedik életévének betöltését követően pedig önállóan dönthet vallásáról („Religionsmündigkeit”, vö. RelKErzG 5. cikk).

13 A német szövetségi választásokra vonatkozó korhatár leszállításáról ld. pl. Knödler, 1996; Hoffmann-Lange - de Rijke, 1996. Életkor és racionális mérlegelés összefüggéséről ld. legújabban Lőrincz, 2018.

14 Schreiber (2004: 1344.) és Vanhuysse (2013) ezt olyan hátránynak tekinti, amelynek egyfajta kompenzációja volna a szülőknek juttatott többletszavazat. 
15 Ezt joggal állítja szembe az előbb tárgyalt, önzetlenségre hivatkozó érvvel de Briey (2007), aki szerint az utóbbi, ti. hogy a szülők érdekei eltérnek a gyermekekétől, mégis tekintettel lesznek majd rájuk a döntéshozatal során, jóval kevésbé meggyőző.

\section{IRODALOM}

Adrian, Axel (2016): Grundsatzfragen zu Staat und Gesellschaft am Beispiel des Kinder-/Stellvertreterwahlrechts: Eine rechtliche Untersuchung mit Bezügen zu Demographie, Demoskopie, Psychologie und Philosophie. Berlin, Duncker \& Humblot. https://doi.org/10.3790/978-3-428-54838-5

Bertaux, Sandrine (2011): Reproduce or Perish? The Artefact of the Fertility Concept and the French School of Demography. Historical Social Research, 36 (2): 120-139. https://doi.org/10.12759/ hsr.36.2011.2.120- 139

Bodnár Eszter (2014): A választójog alapjogi tartalma és korlátai. Budapest, HVG-Orac.

Böckenförde, Ernst-Wolfgang (1982): Mittelbare/repräsentative Demokratie als eigentliche Form der Demokratie: Bemerkungen zu Begriff und Verwirklichungsproblemen der Demokratie als Staats- und Regierungsform. In: Georg Müller (Hrsg.): Staatsorganisation und Staatsfunktionen im Wandel: Festschrift für Kurt Eichenberger zum 60. Geburtstag. Basel-Frankfurt, Helbing \& Lichtenhahn. 301-328.

Cupit, Geoffrey (1998): Justice, Age, and Veneration. Ethics, 108 (4): 702-718. https://doi.org/ $10.1086 / 233848$

De Briey, Laurent (2007): Droit de vote des enfants par procuration. In: Vincent Bourdeau - Roberto Merrill (dir.): DicoPo. Dictionnaire de théorie politique. http://www.dicopo.org.

De Briey, Laurent - Héraut, Aurélie - Ottaviani, Elise (2009): On Behalf of Children? The Plural Voting System in Belgium - from 1893 to 1919. Intergenerational Justice Review, 9 (4): 144-145.

Demeny, Paul (1986): Pronatalist Policies in Low-Fertility Countries: Patterns, Performance, and Prospects. Population and Development Review, 12 (Supplement): 335-358. DOI: 10.2307/2807916

Demeny, Paul (2012): Geopolitical Aspects of Population in the Twenty-First Century. Population and Development Review, 38 (4): 685-705. https://doi.org/10.1111/j.1728-4457.2012.00532.x

Fröhlich, Johanna (2011): Alapkérdések a családi választójog vitájában. Pázmány Law Working Papers, 2011/20. http://plwp.eu/docs/wp/2012/2011-20.pdf.

Gaa, Meinhard (1997). Familienwahlrecht bei den nächsten Bundestagswahlen? Zeitschrift für Rechtspolitik, 30 (8): 345-346.

Goerres, Achim - Tiemann, Guido (2009): Kinder an die Macht? Die politische Konsequenzen des stellvertretenden Elternwahlrechts. Politische Vierteljahresschrift, 50 (1): 50-74.

Hattenhauer, Hans (1996): Über das Minderjährigenwahlrecht. JuristenZeitung, 51 (1): 9-16. [repr. in Palentien-Hurrelmann (Hrsg.): Jugend und Politik, 238-259.]

Hermann, Udo (2011): Ökonomische Analyse eines Kinderwahlrechts. PhD-értekezés, Freie Universität Berlin. http://www.diss.fu-berlin.de/diss/servlets/MCRFileNodeServlet/FUDISS_derivate_000000015340/veroeffentlichung_hermann_online.pdf.

Hinrichs, Karl (2002): Do the Old Exploit the Young? Is Enfranchising Children a Good Idea? European Journal of Sociology, 43 (1): 35-58. https://doi.org/10.1017/s0003975602001017 


\section{A „CSALÁDI VÁLASZTÓJOG” ÉS A VÁLASZTÓJOGI KÉPVISELET KÉT LEHETSÉGES ÉRTELME}

Hoffmann-Lange, Ursula - de Rijke, Johann (1996): 16jährige Wähler - erwachsen genug? Die empirischen Befunde. Zeitschrift für Parlamentsfragen, 27 (4): 572-585.

Hurrellmann, Klaus (1997): Für eine Herabsetzung des Wahlalters. In: Palentien-Hurrelmann (Hrsg.): Jugend und Politik, 280-289.

Jakab, András (2016): Sustainability in European Constitutional Law. MPIL Research Paper No. 2016-16. https://doi.org/10.2139/ssrn.2803304

Jakab, András (2017): Is Suffrage for Children the Constitutional Solution for the Sustainability Challenge Faced by Democracies? In: Iulia Motoc - Paulo Pinto de Albuquerque - Krzysztof Wojtyczek (eds.): New Developments in Constitutional Law: Essays in Honour of András Sajó. Schiedam, Eleven. 213-224.

Jesse, Eckhard (2003): Reformvorschläge zur Änderung des Wahlrechts. Aus Politik- und Zeitgeschichte, 52. (december 22.). 3-11.

Kahl, Wolfgang (2009): Staatsziel Nachhaltigkeit und Generationengerechtigkeit. Die Öffentliche Verwaltung, 62 (1): 2-13.

Kiesewetter, Benjamin (2009): Dürfen wir Kindern das Wahlrecht vorenthalten? Archiv für Rechtsund Sozialphilosophie, 95 (2): 252-273.

Knödler, Christoph (1996): Wahlrecht für Minderjährige - eine gute Wahl? Zeitschrift für Parlamentsfragen, 27 (4): 553-571.

Kurunczi Gábor (2018): Az általános választójog elvének aktuális kihívásai. Államtudományi Múhelytanulmányok, 3. www.allamtudomany.hu.

Kymlicka, Will - Donaldson, Sue (2017): Inclusive Citizenship Beyond the Capacity Contract. In: Ayelet Schachar - Rainer Bauböck - Irene Bloemraad - Maarten Vink (eds.): The Oxford Handbook of Citizenship. Oxford: Oxford University Press. 838-859. https://doi.org/10.1093/oxfordhb/ 9780198805854.013.36

Lőrincz Viktor (2018): Fenntarthatóság, életkor és cselekvőképesség - néhány döntéselméleti és pszichológiai szempont. Magyar Tudomány, 179 (3): 383-393. https://doi.org/10.1556/ 2065.179.2018.3.8

Löw, Konrad (1974): Das Selbstverständnis des Grundgesetzes und wirklich allgemeine Wahlen. Politische Studien, 25 (213): 19-29.

Löw, Konrad (2002a): Kinder und Wahlrecht. Zeitschrift für Rechtspolitik, 35 (10): 448-450.

Löw, Konrad (2002b): Ist das Wahlrecht übertragbar? Beispiele europäischer Nachbarstaaten. Das Parlament, 37-38. (szeptember 17-23.).

Löw, Konrad (2005): Kann ein allgemeines Wahlrecht die demographische Katastrophe abbremsen? Medizin und Ideologie, 27 (4): 34-41.

M. Balázs Ágnes (2017): Családi választójog és fenntarthatóság. Parlamenti Szemle, 1 (1): 47-65.

M. Balázs Ágnes (2018): A plurális választójog fogalma és megengedhetősége napjainkban. Államtudományi Mühelytanulmányok, 6. www.allamtudomany.hu.

Marschall, Stefan (2000): Wer vertritt wen? Volksentscheide und die Funktionslogik parlamentarischer Repräsentation. Kritische Anmerkungen zu einem Beitrag von Winfried Steffani in Heft 3/99 der ZParl. Zeitschrift für Parlamentsfragen, 31 (1): 182-187.

Meixner, Gerhart (2013): Plädoyer für ein „höchstpersönliches Elternwahlrecht zugunsten der Kinder". Zeitschrift für Parlamentsfragen, 44 (2): 419-426. 
Merk, Peter (1997): Wahlrecht ohne Altersgrenze? In Palentien - Hurrelmann (szerk.): Jugend und Politik. 260-279.

Merk, Kurt-Peter (2009): Das Wahlrecht von Geburt an und seine politische Bedeutung. Diskurs Kindheits- und Jugendforschung, 4 (4): 525-538.

Müller-Franken, Sebastian (2013): Familienwahlrecht und Verfassung: Veränderungen des Wahlrechts zugunsten von Familien als Reaktion auf den demographischen Wandel auf dem Prüfstand des Verfassungsrechts. Tübingen, Mohr Siebeck.

Niebel, Dirk - Zypries, Brigitte (2008): Wahlrecht für Kinder? Zeitschrift für Rechtspolitik, 41 (8): 271. p.

Nopper, Klaus Michael Andreas (1999): Minderjährigenwahlrecht: Hirngespinst oder verfassungsrechtliches Gebot in einer grundlegend gewandelten Gesellschaft? Tübingen, Köhler.

Offe, Claus (1994): Zusatzstimmen für Eltern - ein Beitrag zur wünschenswerten Reform von Demokratie und Wahlrecht? In: G. Grözinger - H. Geiger (Hrsg.): Zukunft wählen. Zusatzstimmen für Eltern? Bad Boll, Evangelische Akademie Bad Boll. 1-21.

Palentien, Christian - Hurrellmann, Klaus (Hrsg.) (1997): Jugend und Politik. Ein Handbuch für Forschung, Lehre und Praxis. Berlin, Luchterhand.

Palentien, Christian (1997): Pro- und Contra-Diskussion zu einer Veränderung des Wahlrechts. In: Palentien-Hurrelmann (Hrsg.): Jugend und Politik. 290-299.

Palmore, Erdman B. (1999): Ageism. Negative and Positive, 2. kiad. New York, Springer.

Pechstein, Matthias (1996): Familienwahlrecht - Verfassungsrechtliche Möglichkeiten. In: Karl H. Fell - Bernhard Jans (Hrsg.): Familienwahlrecht - pro und contra. Grafschaft, Vektor. 7-21.

Peschel-Gutzeit, Lore Maria (1999): Das Wahlrecht von Geburt an: Ein Plädoyer für den Erhalt unserer Demokratie. Zeitschrift für Parlamentsfragen, 30 (2): 556-563.

Peterson, Paul E. (1992): An Immodest Proposal. Daedalus, 121 (4): 151-174.

Rehfeld, Andrew (2011): The Child as Democratic Citizen. Annals of the American Academy of Political and Social Science, 633: 141-166. https://doi.org/10.1177/0002716210383656

Reimer, Franz (2004): Nachhaltigkeit durch Wahlrecht? Verfassungsrechtliche Möglichkeiten und Grenzen eines „Wahlrechts von Geburt an“. Zeitschrift für Parlamentsfragen, 35 (2): 322 339.

Reimer, Franz - Schanda, Balázs (2016): Improving Representation by Parental Proxy Voting? In: László Komáromi - Zoltán Tibor Pállinger (eds.): Good Governance - Enhancing Representation. Budapest, Pázmány Press. 63-74.

Rosenberg, Jonas Hultin (2016): The All-Affected Principle and its Critics. A Study on Democratic Inclusion. Uppsala, Acta Universitatis Upsaliensis.

Sanderson, Warren C. - Scherbov, Sergei (2007): A Near Electoral Majority of Pensioners. Prospects andPolicies.Population andDevelopmentReview, 33 (3):543-554.DOI:10.1111/j.1728-4457.2007.00184.x

Schanda Balázs (2012): A jog lehetőségei a család védelmére. Iustum Aequum Salutare, 8 (2): 77-88.

Schreiber, Wolfgang (2004): Wahlrecht von Geburt an - Ende der Diskussion? Deutsches Verwaltungsblatt, 119 (21): 1341-1348.

Schroeder, Werner (2003): Familienwahlrecht und Grundgesetz. JuristenZeitung, 58 (19): 917-922.

Steffani, Winfried (1999): Das magische Dreieck demokratischer Repräsentation: Volk, Wähler und Abgeordnete. Zeitschrift für Parlamentsfragen, 30 (3): 772-793. 


\section{A „CSALÁDI VÁLASZTÓJOG” ÉS A VÁLASZTÓJOGI KÉPVISELET KÉT LEHETSÉGES ÉRTELME}

Toulemon, André (1948): Influence du vieillissement de la population sur la composition du corps électoral. In: Actes des journées pour l'étude scientifique du vieillisement de la population. Paris, Alliance nationale contre la dépopulation. 107-115.

Vanhuysse, Pieter (2013): Measuring Intergenerational Justice - Toward a Synthetic Index for OECD Countries. In: Daniel Schraad-Tischler - Najim Azahaf (eds.): Intergenerational Justice in Aging Societies: A Cross-national Comparison of 29 OECD Countries. Gütersloh, Bertelsmann Stiftung. 10-61. https://doi.org/10.2139/ssrn.2309278

Van Parijs, Philippe (1998): The Disfranchisement of the Elderly, and Other Attempts to Secure Intergenerational Justice. Philosophy and Public Affairs, 27 (4): 292-333. https://doi.org/10.1111/ j.1088-4963.1998. tb00072.x

Weber, Max (1958): Wahlrecht und Demokratie in Deutschland. In: uő: Gesammelte politische Schriften. Tübingen, Winckelmann. 233-279.

Wernsmann, Rainer (2005): Das demokratische Prinzip und der demographische Wandel: Brauchen wir ein Familienwahlrecht? Der Staat, 44 (1): 43-66.

Westle, Bettina (2006): „Wahlrecht von Geburt an” - Rettung der Demokratie oder Irrweg? Zeitschrift für Parlamentsfragen, 37 (1): 96-114. 